\title{
A KIS ALAKVÁLTOZÁSOK ELVÉNEK ALKALMAZÁSA KÖZELÍTÓ SZÁMÍTÁSOK KIDOLGOZÁSÁHOZ
}

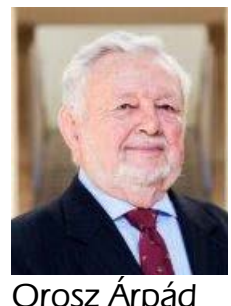

https://doi.org/10.32969/VB.2021.2.3

A korszerü nagy teljesitményü számitástechnikai módszerek megállithatatlan fejlödése mellett is szükség van egyszerüen kezelhetö, a gyakorlat és biztonság igényeit kielégitö pontosságú közelítő módszerekre. A dolgozat bemutatja, hogy a mechanikából ismert kis alakváltozások elvének alkalmazása esetén a közelitö módszerek kidolgozásához elegendö az egyensúlyi feltételek teljesitése. Az épitömérnöki tartószerkezetekben az igénybevételeket néhány százalékos pontossággal kell meghatározni. A pontosságot a valósághü erötani modell, a számitási módszer, valamint a felhasznált alapadatok megbízhatósága határozza meg.

Kulcsszavak: kis alakváltozások elve, mérnöki pontos-ság, erőtani modell, számítási módszer, biztonság

\section{BEVEZETÉS}

Az emberi, de különösen a mérnöki tevékenység célja egy tökéletes, abszolút pontos létesítmény megvalósítása. Ezt a célt különbözö, itt most nem részletezett okok miatt csak bizonyos pontossággal lehet elérni. A közvéleményben általánosan elterjedt fogalom, az úgynevezett „mérnöki pontosság”. A pontosság és a vele analóg gondosság igénye a mérnöki tevékenység minden területére, így a tervezés, a megvalósítás, a tudományos kutatás, az üzemeltetés területére kiterjed.

A jelen dolgozatban csak a tervezés, azon belül is csak az erőtani számítással kapcsolatos pontossági követelményeket, problémákat vizsgáljuk, az építőmérnöki szakterületre korlátozva.

\section{A MÉRNÖKI FELADAT MEGOLDÁSA}

Felvetődik a kérdés, ki is az a mérnök? Röviden az alábbiak szerint határozhatjuk meg:

„A mérnök a társadalomnak az az elhivatott tagja, egy nagyszerü mesterség müvelője, aki a természeti erőforrásokat a természettudományok segítségével, másokkal együttmüködve, olyan alkotások, létesítmények megvalósítására fordítja, amelyek a társadalomcéljait szolgálják."

Ezek megvalósításához a társadalom tulajdonában lévő eszközöket használja, ezért a rendeltetés szerinti müködésükért felelösséggel tartozik. A felelősség arra kényszeríti, hogy munkáját gondosan és pontosan végezze.

\subsection{A társadalmi igény meghatá- rozása, felmérése}

A mérnöki feladat megoldásának első lépése különösen gondos elökészítést igényel. A jelenlegi helyzet mellett, a fejlődés iránya, gyorsasága meghatározó jelentőségü, ezért ezt tapasztalt szakértőkre kell bízni.

\subsection{A létesítmény szerkezeti rend- szere kialakításának megvá- lasztása}

A tapasztalat szerint végtelen sok megoldás létezik, és ezek közül kell kiválasztani a valamilyen szempont szerint meghatározott optimumot. Ezek lehetnek üzemeltetési, funkcionális, szerkezeti rendszer, erőtani, pénzügyi, tartóssági, megvalósítási idő iránti, technológiai, fenntartási stb. igények. Az optimum közelében több, lényegében azonos értékủ megoldás található. Az ezek közötti választáshoz jelentős tapasztalatra van szükség és közelítő módszerek alkalmazhatóak. Egy pályázathoz csak egy kiemelt változathoz kell részletesebb igazolást kidolgozni. E vizsgálat során például az erőtani számításokat már pontosnak tekintett módszerekkel kell elvégezni.

\section{A pontossági igénye}

A pontosság a valóságtól való eltérés mértéke. Miben mérjük a pontosságot? A mértékegységekben való meghatározás az összehasonlítást lehetetlenné teszi, ezért a legegyszerübb és általánosan használható a százalékban való meghatározás. Az építőmérnöki területen a tartószerkezetek erőjátékának vizsgálata során a pontossági igény 3-5 százalékban a szerkezeten megjelenő alakváltozások esetében egy nagyságrenddel szigorúbbak a követelmények, és ez 1-2 ezrelékben határozható meg.

\subsection{Az erőtani vizsgálat}

\subsubsection{Az erőtani számítási modell}


A tervezés egyik legfontosabb része a teherviselő szerkezet erőjátékának, biztonságának meghatározása. Ehhez a mérnök a matematika eszközeit használja. A szerkezet kialakítása alapján egy egyszerüsített, idealizált úgynevezett matematikai modellt alkot, és a számításokat ezen hajtja végre. Ez a modellalkotás rendkívül nagy tapasztalatot igényel, ugyanis többféle modellt lehet kialakítani, és a valóságot az adott esetben legjobban megközelítőt kell alkalmazni. A kiválasztott matematikai modellen végrehajtott számításnak azonban csak egy megoldása van. A számítási módszerek különbözőek lehetnek, így analitikus, iterációs, grafikus stb. eljárásokat lehet alkalmazni, azonban csak egy megoldás létezik, mindegyik ugyanazt a végeredményt szolgáltatja. A mérnöki szerkezet erőtani vizsgálatában alkalmazott eljárások az alábbi részekre épülnek:

\subsubsection{Számítási módszerek, eljárások}

Az ó és középkori tapasztalaton alapuló módszerek után, néhány száz évvel ezelőtt kialakultak és rendkívül gyorsan fejlődtek az egyszerü analitikus, grafosztatikus, majd erő és mozgás módszerek, később megjelent a végeselemes módszer a számítástechnika és ez alapvető változást jelentett. A fejlődés rendkívül gyors, a megbízhatóság, pontosság jelentősen növekedett és a több dimenziós eljárások is megjelentek.

\subsubsection{Terhek és hatások}

A számítási módszerekben alkalmazott terheket és hatásokat a szabályzatok részletesen meghatározzák, ezek közül egyet emelünk ki, nevezetesen a mozgó teherből származó dinamikus igénybevételek meghatározását. Az átlagos építőipari szerkezetek esetében a pontosabb - a tömeg, a sebesség stb. figyelembevételével - kidolgozott módszerek helyett azt az egyszerübb módszert alkalmazzák, amely szerint a statikus igénybevételeket egy a szabályzatokban meghatározott dinamikus tényezővel megszorozzák. Ezek a dinamikus tényezők átlagos értékek és így közelítések, pontatlanságot tartalmaznak. Pontosnak tekinthető dinamikai vizsgálatra, csak kiemelt jelentőségü létesítmények esetében van szükség. Dinamikai jellegü a földrengésből származó hatások számítása.

\subsubsection{Az alkalmazott anyagok}

A felhasznált anyagok előállítási technológiái, szilárdsági és egyéb tulajdonságai jelentősen fejlődtek. Itt a beépített anyagok minőség ellenőrzésének fejlesztése a feladat. Tervezés esetén a szabályzati előírásokat, ellenőrzés során a beépített anyagokat kell figyelembe venni.

\subsubsection{A biztonság}

A biztonság és a kockázat egymás reciprokai. Biztonságos valami akkor, ha a meghibásodás valószínűsége egy bizonyos szintet nem halad meg. A biztonsági szintek pl. az alábbiak: ideiglenes 3 5 évre épülő létesítménynél minden ezredik $\left(10^{3}\right)$, a 100 évre épülő átlagos létesítmény esetén minden tízezredik $\left(10^{4}\right)$, a 100 évnél hosszabb időre készülő kiemelt létesítmény esetében minden százezredik $\left(10^{5}\right)$ tönkremenetele valószínüsíthető. A szintekbe való besorolást, a biztonsági tényezőket és alkalmazásuk módját a szabályzatok, előírások tartalmazzák. A kezdeti egységes biztonsági tényezőt felváltó osztott biztonsági tényezős módszer jelentős fejlődést hozott, de a pontosságot ezek megválasztása határozza meg. A biztonsági tényező a tönkremenetelt jelzi, törés, azaz tönkremenetel esetén ez elég jól meghatározható, a használhatóságot jelző határ megállapításánál viszont szubjektív tényezők is jelentkezhetnek.

\section{A MÉRTÉKADÓ, ILLETVE A HATÁRIGÉNYBEVÉTELEK MEGHATÁROZÁSA}

A kiválasztott erőtani modellen ki kell számítani az igénybevételek, alakváltozások stb. alapértékeit. A szabályzatokban előírt biztonsági tényezőkkel és csoportosítással a mértékadó, illetve határigénybevételek (tervezési értékek) meghatározhatóak. Ezek tehát nem valóságos, hanem fiktív, számított értékek, mennyiségek. Nagyságukat, pontosságukat az alkalmazott tényezők, csoportosításuk rendszere határozza meg. A változatos tényezők és csoportosítás miatt a pontossági követelmény meghatározása bizonytalan. A pontossági igény, mint korábban említettük, 3-5 \%-ban határozható meg. Amennyiben a számításnál a bemenő adatok valószínüségi változók, akkor a pontosság is az.

\section{ALAKVÁLTOZÁSOK, ELMOZ- DULÁSOK, FESZÜLTSÉGEK}

\subsection{A kis elmozdulások elve}

Általános esetben a külső teher hatására létrejövő alakváltozások és feszültségek közötti összefüggések meghatározása bonyolult feladat. A mechanikából, illetve az elemi szilárdságtanból ismert a kis elmozdulások elve, amely lehetővé teszi közelítő feltevések bevezetését, és a számítások egyszerüsítését. Ilyen például a hajlított tartónál a sík keresztmetszetek feltevése, amely Bernoulli-Navier törvény néven ismert. A kis elmozdulások elvének alkalmazását az elemi szilárdságtanban azzal indokolják, hogy egy híd, illetve tartó gerenda lehajlása a fesztávolsághoz viszonyítva nagyon kicsiny, a fesztávolság ötszázad- egy ezredénél is kisebb. Kis alakváltozásnak tekintjük, tehát az 1-2 ezrelék vagy ennél kisebb elmozdulásokat (Kaliszky et.al, 1990)

\subsection{Egyenes hajlítás}

Az elemi szilárdságtanban, ha csak „tiszta hajlítás” müködik, azaz a nyíróerő zérus, akkor a normálfeszültséget a jól ismert képlettel lehet meghatározni, azaz:

$\sigma=\frac{M}{J} y=\frac{M}{K}$

Itt feltételezték a Bernoulli-Navier elv, azaz a kis elmozdulások elvének érvényességét. A képlet levezetése során csak egyensúlyi feltételeket használtak, azaz az alakváltozásokat elhanyagolták.

\subsection{Hajlítás és nyírás}

Összetett igénybevételek, azaz M hajlítónyomaték és Q nyíróerő egyidejü müködése esetén az elemi szilárdságtanban az alábbi összefüggést vezették be:

$\tau_{y z}=\frac{Q S_{x}}{J_{x} S}$ 
a képletnek a levezetése során felhasználták a tiszta hajlítás esetén érvényes összefüggést (1) (Kaliszky et al 1990). Ez logikai ellentmondást jelent, mert feltételezték, hogy valami nincs, és az így kapott eredményt alkalmazták annak a meghatározására, hogy mekkora az, ami nincs. Itt is érvényesnek tekintették a sík keresztmetszet elvét.

\subsection{A csavarás}

Ezzel kapcsolatban csupán annyit emelünk ki, hogy itt is érvényesnek tekintik a kis alakváltozások elvét, azaz a keresztmetszet öblösödésének a hatását nem vizsgálják. Az így kapott képlet

$$
\tau_{z}(r)=\frac{T}{I_{0}} r
$$

Az (1) (2) (3) jelü képletek tehát tulajdonképpen közelítések, azonban pontosságuk a gyakorlati igényeket kielégíti, ezért általánosan használtak és a gyakorlatban már pontosaknak tekinthetök.

\section{PÉLDÁK}

\subsection{A silónyomások}

Janssen 1895-ben modellkísérletek alapján megállapította, hogy a silóban tárolt anyag súlyának egy része a cella fenéklemezén keresztül, a másik része a falon való súrlódással közvetlenül adódik át az alapozásra. A silóban nyugalomban lévő anyag esetén a nyomásviszonyok számítással való meghatározására az ábrán látható cellán egy d magasságú elemi részre ható nyomások egyensúlyára az alábbi egyenletet írta fel. (Bölcskei, Orosz, 1971)

$\mathrm{F} \gamma d \mathrm{z}+\mathrm{p}_{\mathrm{v}} \mathrm{F}-\left(\mathrm{p}_{\mathrm{v}}+\mathrm{dp} \mathrm{p}_{\mathrm{v}}\right) \mathrm{F}-\mathrm{p}_{\mathrm{s}} \mathrm{Kdz}=0$

- $\gamma$ a tárolt anyag térfogatsúlya

- A függőleges nyomás: $p_{\mathrm{v}}$

- A vízszintes nyomás: $\mathrm{p}_{\mathrm{h}}=\mathrm{kp}_{\mathrm{v}}$ ahol $\mathrm{k}=1-\sin \phi$ a földnyomás elméletből ismert tényező

- A surlódó nyomás: $\quad \mathrm{p}_{\mathrm{z}}=\mu \mathrm{p}_{\mathrm{h}}=\mu \mathrm{kp}_{\mathrm{v}} \quad$ ahol $\mu$ a falsúrlódási tényező.

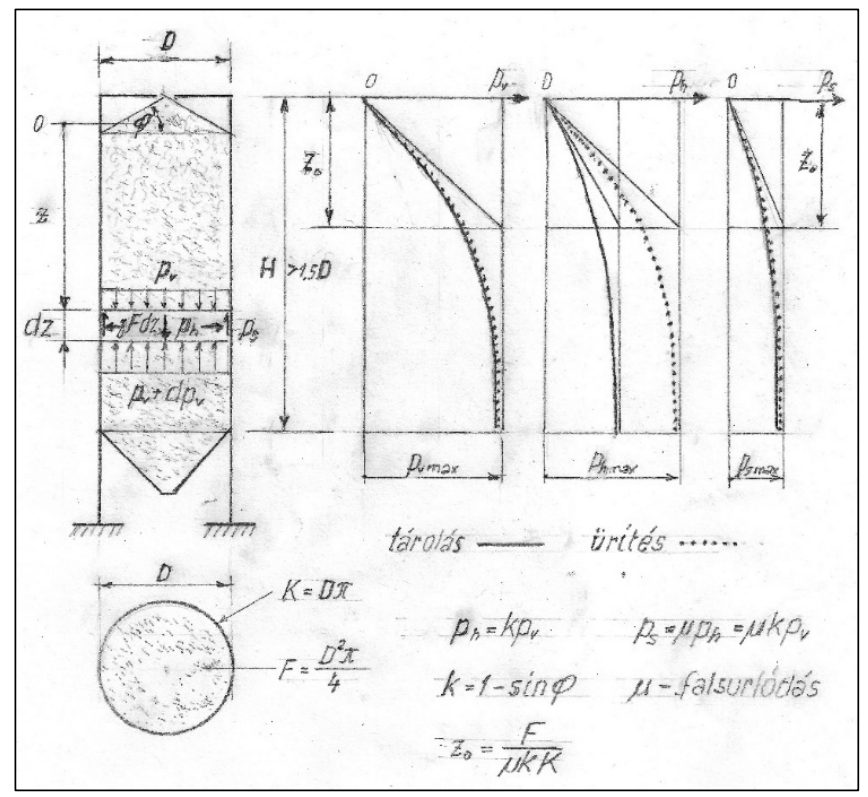

1. ábra: A silónyomás
Az 1. ábra jelöléseivel felírt egyensúlyi egyenlet három ismeretlent tartalmaz. Bevezetve a $z_{0}=\frac{F}{\mu k K}$ mennyiséget, és felhasználva a $\mathrm{p}_{\mathrm{h}}$ és $\mathrm{p}_{\mathrm{s}}$ előzőek szerinti meghatározását, rendezés után az alábbi elsőrendü differenciálegyenletet kapjuk, amely csak egy ismeretlent, a $p_{\mathrm{v}}$ függőleges nyomást tartalmazza.

$\frac{d p_{v}}{d z}=\gamma\left(1-\frac{1}{z_{0} \gamma} p_{v}\right)$

A kezdeti feltétel a $\mathrm{z}=0$ helyen $\mathrm{p}_{\mathrm{v}}=0$, így a megoldás:

$p_{v}=z_{0} \gamma\left(1-e^{-\frac{z}{z_{0}}}\right)$

$\mathrm{Z}=\infty$ esetében a legnagyobb nyomások:

$p_{v \max }=\gamma z_{0}$

$p_{\text {hmax }}=k \gamma z_{0}$

$p_{\text {smax }}=\mu k \gamma z_{0}$.

Az (5) jelű egyenlet tehát csak egyensúlyi feltételeket tartalmaz, az alakváltozásokat nem veszi figyelembe, a kis alakváltozások elvének alkalmazásával, így ez tulajdonképpen egy közelítő számítási modell, a (6) megoldás azonban a gyakorlat számára pontosnak tekinthető. Azt, hogy ez a modell elfogadható az bizonyítja, hogy a megoldás valósághüen adja meg a nyomások tényleges, exponenciálisan csökkenő eloszlását. A megoldás, azaz a számítási eljárás pontosságát akkor az úgynevezett bemenő adatok, a $\gamma$, a k, és a $\mu$ tényezők határozzák meg. A természetes nagyságban gabonasilókon végrehajtott kísérletek szerint tárolás esetében $\mathrm{k}_{\mathrm{t}}=0,5, \mu_{\mathrm{t}}=0,4$ ürítéskor $\mathrm{k}_{\ddot{\mathrm{u}}}=1$ és $\mu_{\mathrm{u}}=0,2$ tényezőkkel a számított értékek a mérési eredményekkel jó egyezést mutattak.

Megjegyezzük, hogy az ürítési állapotban a pontos vizsgálathoz a mozgásban lévő anyagra vonatkozó dinamikai egyenleteket kellene alkalmazni, ami nyilvánvalóan bonyolult lenne.

A felvázolt közelítés hasonló a tartószerkezetek esetében alkalmazott eljáráshoz, ahol dinamikus hatásokat úgy veszszük figyelembe, hogy a statikus értékeket egy dinamikus tényezővel megsyoroyyuk. Az előzőek alapján nyilvánvaló, hogy a modell meghatározása alapvető jelentőségü, mert ha a jelenség a hatások leírására alkalmas, akkor a hozzá kapcsolt számítási módszerekben már közelítéseket, feltételezéseket is lehet alkalmazni. A silónyomásokkal kapcsolatos kísérleti eredményeket az (Orosz-Simurda 1985) (Orosz-SimurdaVarga 1990) (Orosz, 2001) (Dulácska-Bódi, 2018) dolgozatok részletesen ismertetik.

\subsection{A mélyalappal gyámolított alaplemezek}

\subsubsection{Cölöpökkel gyámolított alaplemez}

A cölöpök kiosztása lehet ritka vagy sürü. A hazai gyakorlat a szerkezettervező szoftverekkel, a rugalmasan ágyazott lemezhez és cölöpökhöz iterációval felvett ágyazási tényezővel és cölöp rugókkal dolgozik. Ezek nem talajfizikai 
paraméterek, nem állandóak, és csak egy pontban érvényesek. Az iterációt több pontban kell végrehajtani, amihez nagyteljesítményű számítógépek szükségesek. Ezzel a pontosnak nevezhető geotechnikai modellel nem foglalkozunk, részletes ismertetés található a (Lődör-Móczár 2018) dolgozatban.

\subsubsection{Réspillérrel gyámolított alaplemezek}

Az alaplemez gyámolítására sikeresen alkalmazhatóak a réseléssel elöállított réspillérek, ugyanis a munkagödör körülhatárolásához szükséges technológia a helyszínen rendelkezésre áll, erre is felhasználható. Az alapozási rendszer kidolgozói elsősorban a megvalósítási technológia fejlesztésére törekedtek, hogy a vasalás szerelése egyszerü, minél kevesebb fajta vasátmérő és vasalás fajta legyen, csökkenjen a helyszíni élőmunka, az anyag és a munka árak optimálisan alakuljanak. Azt az alapelvet fogadták el, amely szerint az ,az elmélet a gyakorlat szolgálóleánya". Részletesen tárgyalják a témát (Orosz 2014,2016) (Orosz, Nagy, Zábrádi, Horváth, Répánszki, 2017) (Orosz, Nagy, 2018) (Nagy, 2019) dolgozatok.

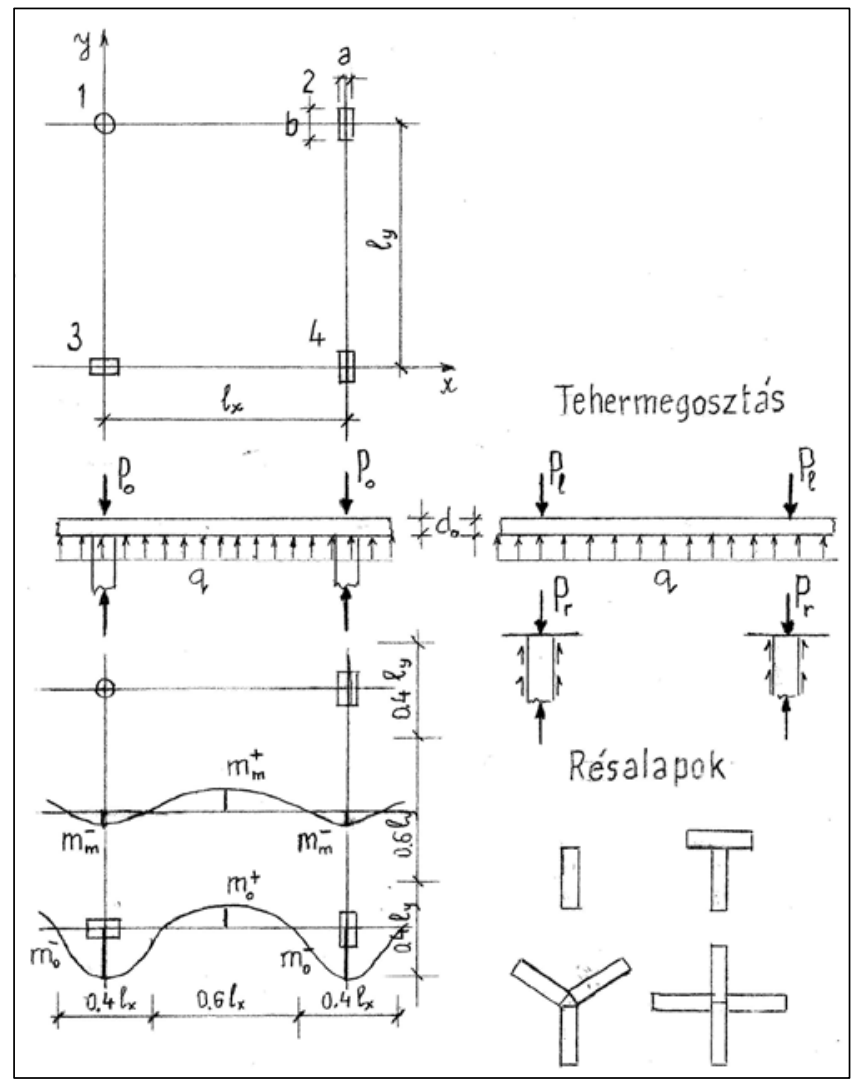

2. ábra: Réspillérekkel gyámolított alaplemez számítási elvei

A ,tartószerkezeti modellnek" nevezhető módszer a tehermegosztás elvére épül, oly módon, hogy a vasbeton alaplemezt választja alapul, ugyanis ennek teherviselö képessége a gyakorlat igényeit kielégítő pontossággal számítható. Az átlagos 50-50\%-os tehermegosztás esetére (meghatározott teherre) a lemez mérete, vasalása mind hajlítónyomatékra, mind átszúródásra jól meghatározható. A teljes teher és a lemezteher különbségére kell méretezni a mélyalapokat, így mindkettő jól kihasznált gazdaságos szerkezeti elem lesz. Az alaplemez igénybevételeit a szakirodalomban található fix alátámasztású síklemezekre kidolgozott táblázatokból számíthatóak. Az alaplemezt tehát fix alátámasztású fordított födémként vizsgáljuk. Ezt az indokolja, hogy jelentős a felszerkezet merevítő hatásának változása, ugyanis már az építés idején oly mértékben nő a szerkezet merevsége, hogy az korlátozza a tehernövekedésböl származó alakváltozásokat. Ennél a módszernél tehát elhanyagoljuk a rugalmas ágyazásból származó mozgásokat. A megépült létesítményeken végzett mérések 1/1000 nagyságrendű alakváltozásokat $1 \mathrm{~cm}$-nél kisebb süllyedés különbségeket jeleztek, azaz a kis alakváltozások elve érvényesnek tekinthető. Nagy előnye ennek az alapozási rendszernek, hogy a tervezés közben megváltozott oszlopterhek esetében az alaplemez vasalás által jól meghatározott teherviselő képessége változatlan maradhat, nem kell vasalási tervet átdolgozni. A többlet teher a réspillérekre hárítható, a tervek is csak ki mértékben módosulnak.

Megjegyezzük, hogy az alapozási rendszer fejlesztése mintegy három évtizede kezdődött, abban az időben még nem léteztek az úgynevezett pontosabb számításhoz szükséges számítástechnikai eszközök és módszerek, így a hagyományos eljárásokra kellett támaszkodni. A tapasztalat szerint, sem a megbízót, sem a közremüködőket nem érdekelte az igénybevételek számítási módszere, az ár és a határidő volt a döntő.

Alapfeltételek :

$$
\begin{array}{ccc}
\frac{l_{x}}{l_{y}}=0.8-1.25 & \text { között }, & d_{0}=\frac{l}{10}-\frac{l}{20} \\
\text { között, } & d_{0}>40 \mathrm{~cm} & a_{\min }=0.4 l
\end{array}
$$

A teljes oszlopteher: $\quad P_{0}$

A résekre hat: $\quad P_{r}=\alpha P_{0}$

A lemezre hat: $\quad P_{l}=(1-\alpha) P_{0} \quad \alpha=0.3-07$

között javasolt $\alpha \cong 0.5$

A talajreakció :

$q=\frac{P_{l}}{l_{x} l_{y}}$

A nyomaték :

$m=c q l_{x} l_{y}=c P_{l}$

Oszlopsáv :

Mezősáv :

$m_{0}^{-}=-0.15 P_{l} m_{0}^{+}=0.05 P_{l}$

$m_{m}^{-}=-0.04 P_{l} m_{m}^{+}=0.05 P_{l}$

A számítás lépései:

- alaplemez felvétele, igénybevételei, vasalása

- tehermegosztás meghatározása,

- átszúródás és

- repedéskorlátozás vizsgálata.

A résalapok elrendezése az 2. ábrán látható, méretezésükre geotechnikai módszereket kell alkalmazni, ezeket itt nem ismertetjük.

Megjegyezzük, hogy a szakirodalomban található táblázatokban szereplő c tényezőket a repedezettség és a merevségváltozás figyelembevételével határoztuk meg.

\section{A SZÁMÍTÁSI MÓDSZEREK ÉTÉKELÉSE, MEGÍTÉLÉSE}

Mind a pontos, mind a közelítő módszerek esetén alapvető követelmény, hogy a gyakorlat igényeit kielégítő pontosságú eredményeket szolgáltassanak. A pontosnak tekintett eljárások esetében a korábban megadott pontossági követelmények a mérvadóak. Közelítés esetén a 10\%-os eltérés még megengedhető. Ennél nagyobb eltérés már becslésnek tekinthető. 
A közelítő módszerek között vannak olyanok, amelyek elsősorban matematikai jellegüek, és a megoldásokat pl. Fourier sorok segítségével határozzák meg. Ezek általánosan használható eljárások. és a gyakorlat számára elegendő pontosságú eredményt szolgáltat a sor első néhány tagjának a figyelembevétele. Ennek a módszernek az előnye, hogy a sor több tagjának a beszámításával, a megoldás pontossága fokozható.

Más típusú közelítő, vagy akár pontosnak tekintett módszerek megítélése már lényegesen bonyolultabb. A szerző, mint egyetemi hallgató 1951-52-ben részt vett Korányi Imre professzor úr előadásain, aki akkor az egységes biztonsági tényezős módszerről, az osztott biztonsági tényezős módszerre való áttérést ismertette. Hangsúlyozta, hogy az egységes tényezős módszer jó és megfelelő, mert az ezzel számított hidak és építmények állnak, és biztonsággal viselik a terheket. Az áttérésre azért van szükség, mert figyelembe lehet venni a terhek és hatások jellegét, az építőanyagok minőségének a számítási módszereknek a fejlődését. Az osztott biztonsági tényezőket úgy kell megválasztani, hogy az új szerkezetekben a felhasznált anyagok 10\%-kal csökkenjenek. Ennél nagyobb eltérés hazardírozásnak tekinthető. Lényegében azt az álláspontot, véleményt képviselte, hogy a számítási módszerek megbízhatóságát meggyőzően a megépült létesítmények bizonyítják, a szerző ezzel teljes mértékben egyetért. Megjegyezzük, hogy elsőként az 1951-es Magyar Szabványban jelent meg az osztott biztonsági tényezős módszer.

A tartószerkezetek számítási pontossági igényeinek meghatározása során figyelembe kell venni az alábbiakat. Az ó és középkorban a tapasztalat volt az elsődleges, az újkori 17-20ik századi elméleti fejlődés során előfordult, hogy az elmélet megelőzte a gyakorlatot. A kétirányban teherviselő lemezelmélet évtizedekkel megelőzte a gyakorlati alkalmazást. Manapság viszont azt tapasztaljuk, hogy a megvalósítási technológiák fejlődése megelőzi az elméleti vizsgálatokat. A réselési, vagy paneles építési módszer kényszerítette az elméleti fejlesztést, igazolást. A technológiák igényei a gyorsaság, az anyag és a munka aránya, a költségek, a hatékonyság stb. az elsődlegesek, és az igénybevételek meghatározásának módszere másodlagos. A biztonság számítással való igazolása viszont kötelező, és a tervezés nélkülözhetetlen része. Az is igaz, ha egy gyakorlott tervező 5-6 (hasonló) szerkezetet megtervezett, akkor egy újabbat minimális számítással el tud készíteni. Mindezek alapján alakult ki a dolgozat szerzőjének az a véleménye, hogy az ,elmélet a gyakorlat szolgálóleánya'. Ez mérnöki szemszögből nézve elfogadható, de az elméleti vizsgálatokra továbbra is szükség van, mert a természeti jelenségek megértéséhez és a hozzájuk való alkalmazkodáshoz a biztos alapok nélkülözhetetlenek. Nyilvánvaló, hogy a létesítmény elöírt biztonságának számítással való igazolására szükség van.

\section{MEGÁLLAPÍTÁSOK}

- Az utóbbi évtizedekben a tartószerkezetek erőtani vizsgálatára új, rendkívül hatékony módszerek jelentek meg, amelyek használatához fejlett számítástechnikai eszközök és ismeretek szükségesek. Ezek lehetővé teszik a korábban kezelhetetlen összetett jelenségek figyelembevételét, a pontosság növelését. Ez a fejlödés megállíthatatlan és szükséges, azonban a bonyolult eredmények gyakorlatban való alkalmazása nehézkessé vált. Szükség van tehát egyszerü, jól kezelhető, de megbízható közelítő módszerekre.

- A közelítő módszereket célszerüen annak kell készítenie, aki a bonyolult elméleti eljárást kidolgozta. Ugyanis ö tudja legjobban, hogy melyek azok a tényezök, amelyek hatása a végeredményre jelentős, illetve csekély. A pontosnak tekinthető elméleti vizsgálat így alapkutatásként, míg a közelítő módszer kidolgozása alkalmazott kutatásként értelmezhető és ezek együttmüködésének szükségességét is jelzi.

- A tartószerkezetek erőjátéka vizsgálatához szükség van egy elméleti modellre, amely pontosnak tekinthető, ha egyensúlyi és alakváltozási feltételekre épül. Az így meghatározott modellen végzett vizsgálat azonban bonyolult, a gyakorlatban nehezen alkalmazható.

- Az építőmérnöki gyakorlatban alkalmazott tartószerkezetek megengedett, eltürt alakváltozásai 1-2 ezred nagyságrendűek, ezért az elemi szilárdságtanban alkalmazott kis alakváltozások elve felhasználható. Így az alakváltozások hatásának elhanyagolásával, csupán az egyensúlyi feltételek figyelembevételével a gyakorlat igényeit kielégítő pontosság érhető el. A kis alakváltozások elve tehát nem csak keresztmetszetre, hanem a tartószerkezetre is kiterjeszthető.

- A mérnöki számítások pontosságát a modell megválasztása döntően meghatározza, ez gyakorlatot és tapasztalatot igényel. Ezt már a mérnökképzésben is célszerü gyakoroltatni, nevezetesen úgy, hogy megadott modellen és terhekkel- minden számítás nélkül alakhelyes igénybevételi és alakváltozási ábrákat kell készíteni. A modell megváltoztatásával, ezt megismételve, a változás elemzését el kell végezni. Ilyen feladatoknak a vizsgákon való számonkérése a felkészülést ösztönzi.

- A tartószerkezetek számítására és megvalósítására szolgáló, jelenleg alkalmazott módszerek hatékonyak, ezt bizonyítja, hogy a megvalósított létesítmények állnak és kellő biztonsággal müködnek, azaz a legmeggyőzőbb bizonyítékokat a megépült szerkezet szolgáltatja.

- A bemutatott 1.sz. példa azt igazolja, hogy elegendő pontosságú eredményt szolgáltat az a modell is, amely egy matematikai módszerrel meghatározott egyensúlyi feltételekkel felépített differenciálegyenlet.

- A 2. példa azt bizonyítja, hogy közelítő módszer kidolgozásához, a modell megválasztása az erőjáték és a mérési adatok elemzése és tapasztalata alapján is lehetséges.

\section{8. ÖSSZEFOGLALÁS}

Általánosan ismert, hogy a mechanikában a keresztmetszetek erőtani vizsgálata a kis alakváltozások elvének alkalmazása esetén, csupán egyensúlyi feltételekkel is lehetséges. A dolgozat bemutatja, hogy ez a módszer a szerkezetekre is kiterjeszthető, és ezáltal olyan közelítő módszereket lehet felépíteni, amelyek csak egyensúlyi feltételeket tartalmaznak. Nyilvánvalóan, ehhez az szükséges, hogy a szerkezet elmozdulásai, alakváltozásai egy meghatározott értéknél kisebbek legyenek. A számítástechnika megállíthatatlan fejlődése miatt ezek a „pontos” módszerek egyre bonyolultabbak, és különleges eszközöket igényelnek. Szükség van tehát olyan egyszerüsített módszerekre, amelyek a gyakorlati igényeket kielégítö „mérnöki pontosságú” eredményeket szolgáltatnak. A bemutatott példák építőipari szerkezetek, más szakterületen külön vizsgálatra van szükség. 


\section{HIVATKOZÁSOK}

Bölcskei E.-Orosz. Á. (1972), „Vasbetonszerkezetek. Faltartók, lemezek, tárolók” Tankönyvkiadó Budapest 1972

Dulácska. E.-Bódi. J. (2018), „A Vasbeton silók repedései és egyéb problémái”, VASBETONÉPÍTÉS 2018/2 pp. 36-40.

Kaliszky S.-Kovács M.-Szilágyi. Gy. (1990), ’Mechanika II. Szilárdságtan”, Tankönyvkiadó Budapest 1990

Lődör K.-Móczár B. (2018), „Cölöppel gyámolított lemezalap vizsgálata geotechnikai végeselem modellezés”, Budapest 2018, Magyar Mérnöki Kamara, Geotechnikai Tagozat

Nagy J.-Orosz. Á. (2019),’Az ötlettől az alapozási rendszerig”, Kézdi Árpád konferencia, pp. 183-203.

Orosz. Á.-Simurda. L.:(1985) Vasbeton gabonasilókkal kapcsolatos vizsgálatok, mérések, kutatások Mélyépitéstudományi szemle 1985/3 pp. 113117

Orosz Á.-Simurda L.-Varga J. (1990), „Design Problems of Reinforced Concrete Silo Walls", Proceedings of the University Adelaide Ausztrália 1990.

Orosz Á. (2001), „Vasbeton silók javítási módszerének megválasztása”, BME Hidak és Szerkezetek Tanszék Tudományos Közleményei 2001, pp. 145-150.
Orosz Á., (2011), „Gondolatok a mérnöki tevékenységről és a mérnöki pontosságról”, Erdélyi Magyar Tudományos Társaság Kolozsvár Románia XV. Nemzetközi Épitéstudományi Konferencia 2011, pp 412-418.

Orosz Á. (2014), ’Réspillérekkel gyámolított vasbeton alaplemez átszúródásának egyszerüsített vizsgálata, a tóruszvasalás alkalmazása”, Erdélyi Magyar Müszaki Tudományos Társaság XVIII. Nemzetközi Épitéstudományi Konferencia 2014, Csíksomlyó, pp. 248-252.

Orosz Á. (2016), „Mélyalappal gyámolított alaplemezek”, BME Hidak és Szerkezetek Tanszék Tudományos Közleményei 2016

Orosz Á. - Nagy J. - Zábrádi E. - Horváth A.- Répáczki I. (2017), „Foundation slabs supported by spot footing”, fib Conference Tokaj CCC2017

Orosz Á.-Nagy. J. (2018), „Réspillérekkel gyámolított alaplemezek erőjátéka, átszúródása, és a tórusz vasalás alkalmazása 1-2 rész", VASBETONÉPÍTÉS 2018/3 1. rész és 2018/4 2. rész

Összefoglaló jelentés (2000) „A Vízép megbízásából az Óbuda Gate irodaház fenéklemezein mért talpfeszültségekről és alakváltozásokról, Kézirat

Dr. Orosz Árpád (1926) okleveles mérnök (1953), professzor emeritus, MÁV Hídépítő Vállalat, Műegyetemi oktató (1956), egyetemi tanár (1967), tanszékvezető (1977-91), Dékán (1991), Ipari Vasbetonszerkezetek, Héjszerkezetek oktatása. Érdeklődési területei: vasbeton silók, folyadéktárolók, mélyépítési mütárgyak, mélygarázsok, vasbetonszerkezetek javítása megerősítése.

\section{SZEMÉLYI HÍREK}

\section{DR. BÉRES LAJOS 85. SZÜLETÉSNAPJÁRA}

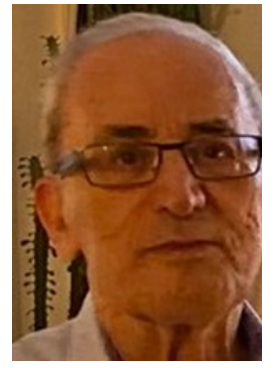

Születésnapja alkalmából a fib Magyar Tagozata tisztelettel köszönti a magyar betontudomány és technika kiváló fejlesztőjét, egyesületünk fennállása óta megbecsült tagtársunkat.

Béres Lajos 1959-ben szerzett mérnöki oklevelet. Már hallgató korában dolgozott demonstrátorként a Müegyetem Beton és Vasbeton Laboratóriumában. Itt került a Tanszék fiatal oktatóival, Balázs Györggyel, Orosz Árpáddal, Szalai Kálmánnal és Tassi Gézával is közelebbi kapcsolatba, amely később életre szóló együttműködéssé, barátsággá alakult.

Pályájának első szakasza az Építéstudományi Intézethez kötődött. Kutatásainak középpontjában a szerkezeti anyagok, elsősorban a beton tulajdonságainak megismerése állt. Az anyagvizsgálatok tökéletesítésére új eljárásokat és laboratóriumi eszközöket fejlesztett ki. Értékes eredményekre jutott a betonok tartós és ismétlődő teher okozta alakváltozásainak és tönkremenetelének kutatásában. Az e tárgykörében írt kandidátusi értekezését 1988-ban védte meg. Tudományos munkásságának eredményeit hazai és nemzetközi szakfolyóiratokban és ÉTI tanulmányokban tette közzé. Az alapkutatásban végzett széleskörü munkája mellett az újszerü építési rendszerek fejlesztése is szívügye volt. Ezek közül különösen jelentősek az előregyártott vasbeton szerkezetek komplex tervezési-kísérleti vizsgálatai. A szakértői szakosztály vezetőjeként számos meghibásodott épület vizsgálatában, a hibák okainak feltárásában és a helyreállítás módjainak kidolgozásában személyesen is részt vállalt. Az ÉTI osztályvezetői, majd műszaki igazgatói posztján jelentős szerepet töltött be. Nevéhez füződik munkahelye kutatásifejlesztési eredményei ipari alkalmazásának nagy része.

Szakterületén és a kapcsolódó tudományágakban is rendszeresen képezte magát. Három nyelvvizsga, szakközgazdász diploma mellett filozófiai és pszichológiai tanulmányokat is végzett. Tapasztalatait a BME-n, illetve a Mérnöktovábbképző Intézet előadójaként adta át a fiatalabb nemzedéknek. Részt vett az MTA, az OMFB munkájában, hazai és nemzetközi szabványok létrehozásában. Két évtizeden át müködött közre a KGST országok építési kutatásaiban és a magyar tagozat irányításában. Feladatokat vállalt a CEB, CIB, RILEM keretében, az ÉTÉ-ben, az MMK-ban és jelenleg is a fib Magyar Tagozatában.

Az 1990 utáni években a Kármán Tamással közösen alapított mérnöki iroda egyik vezetőjeként kamatoztatta szakmai tapasztalatait, szervezőkészségét és közgazdasági ismereteit. Részt vett vállalatok átalakításában, privatizációjában, az új cégek tevékenységének felügyelőbizottsági ellenőrzésében. Másfél évtizeden keresztül külföldi bankok által finanszírozott magyarországi nagyberuházások pénzügyi-müszaki ellenőrzését is végezte.

Az építés és ingatlanforgalom területén 1995-től végzett rendszeresen igazságügyi szakértői tevékenységet. Ennek keretében minden kirendelésnél más és más müszaki és gazdasági problémát kellett megismernie és megoldania. Ez megkövetelte az érintett szakterület aktuális állapotával, (gyakran változó) szabályozási kérdéseivel kapcsolatos naprakész ismereteket. Mindez nagyban segítette abban, hogy szellemileg friss maradjon.

Egészségi állapota - és a pandémia miatt is - cégüket, az X-PER-T Mérnöki Iroda Kkt-t 2020 végén felszámolta és az igazságügyi szakértői jogosultságáról is lemondott. Ezt követően - a felesége által már megkezdett - családkutatásra, a kapcsolódó dokumentumok gyüjtésére, feldolgozására fordítja energiáját, és közösen igyekeznek a másfél éve internetkapcsolatra korlátozott szakmai, baráti kapcsolatrendszerüket újra feléleszteni.

Kedves barátunknak a hasznos és kedve szerinti tevékenységéhez további sok erőt, sikert, jó egészséget, családja körében sok örömet kívánunk. 